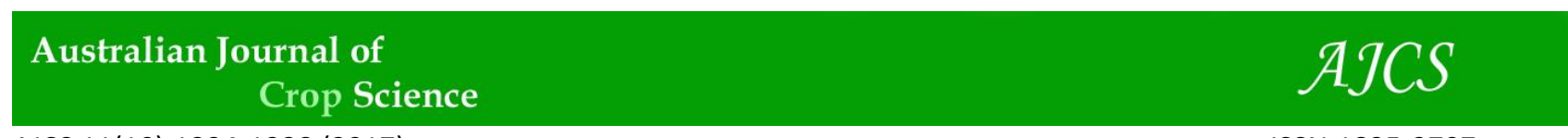

AJCS 11(10):1334-1338 (2017)

ISSN:1835-2707

doi: 10.21475/ajcs.17.11.10.pne611

\title{
Chemical attributes of archaeological black earth soils in Brazilian Amazon
}

\section{Keila Christina Bernardes ${ }^{1 *}$, Maria de Lourdes Pinheiro Ruivo², Augusto José Silva Pedroso ${ }^{3}$, Possidônio Guimarães Rodrigues ${ }^{4}$, Ricardo Shigueru Okumura ${ }^{4}$}

\author{
${ }^{1}$ Instituto Nacional de Colonização e Reforma Agrária, Manaus city, Brazil \\ ${ }^{2}$ Centro de Ciências da Terra, Museu Paraense Emilío Goeldi, Belém city, Brazil \\ ${ }^{3}$ Instituto Federal de Educação, Ciência e Tecnologia do Pará, Castanhal city, Brazil \\ ${ }^{4}$ Universidade Federal Rural da Amazônia, Paragominas city, Brazil
}

*Corresponding author: keilabernardes.agro@hotmail.com

\begin{abstract}
The substrate of Archaeological Black Earth (ABE) in archaeological sites is characterized by presence of anthropogenic A horizon that contains ceramic fragments and lithic artifacts of indigenous pre-Columbian origin. The aims of this study were to evaluate modification of chemical attributes of soils promoted by anthropic activities carried out in areas around archaeological sites soils in Northeast Pará Islands region. The study areas were located in Barcarena city (Alunorte site), Abaetetuba city (Bittencourt site), and Moju city (Jambuaçu site), State of Pará, Brazil. The experimental design was performed using randomized block design in situ with a collection of $7 \mathrm{ABE}$ profiles at Alunorte site; $12 \mathrm{ABE}$ profiles samples at the Bittencourt site and 6 ABE profiles samples at Jambuaçu site. The soil chemical attributes such as $\mathrm{pH}, \mathrm{C}, \mathrm{OM}, \mathrm{N}, \mathrm{C} / \mathrm{N}, \mathrm{Na}, \mathrm{K}^{+}, \mathrm{Ca}^{+2}, \mathrm{Mg}^{+2}, \mathrm{SB}, \mathrm{Al}^{+3}, \mathrm{H}+\mathrm{Al}, \mathrm{CEC}$ ef $\% \mathrm{~V}, \% \mathrm{~m}$ and $\mathrm{P}$ data were subjected to Tukey's test and to multivariate analyzer for principal component and cluster analysis. Jambuaçu site contained higher carbon, organic matter, magnesium, sum of bases, potential acidity, cation exchange capacity and phosphorus values compared to Bittencourt and Alunorte sites. Bittencourt site has characteristics such as $\mathrm{pH}$, potassium, calcium and saturation consistent basis with values observed in ABE soils, while Alunorte site has no chemical characteristics like ABE features. Principal component analysis showed that variables such as organic matter and cation exchange capacity were most distinct among the archaeological sites soils (Alunorte, Bittencourt and Jambuaçu site).
\end{abstract}

Keywords: Anthropogenic soils, Brazilian Amazon, Soil fertility.

Abbreviations: ABE_archaeological black earth, PCA_principal component analysis, P_phosphorus, Ca_calcium, Mg_magnesium,

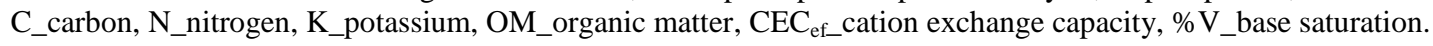

\section{Introduction}

Archaeological evidence indicates that ancient human activities in Amazonian habitats have significantly transformed landscapes in the vicinity of their settlements, amidst the vast Amazon region occurs areas in which the original feature of the soil has been modified by anthropic processes. Such soils are known as Archaeological Black Earth (Costa et al., 2013). The Archaeological Black Earth (ABE) substrate in archaeological sites is characterized by presence of anthropogenic A horizon that contains ceramic fragments and lithic artifacts of indigenous pre-Columbian origin (Lima et al., 2002). It is found in various soil types such as Latossolo, Argissolo, Luvissolo, Neossolo and Cambissolo (Smith, 1980). Soils in the Amazon are generally acidic and have low nutrient availability, especially phosphorus. However, in the same environment, there are black soil stains of archeological black soil with high values of organic matter and nutrients (phosphorus and calcium) (Aquino et al., 2016). The Archaeological Black Earth (ABE) in the Amazon is practically distributed in all regions. However, it is estimated that there may be hundreds of sites scattered in the region, and may cover about $10 \%$ along the basin (Pessoa and Santana, 2017). Waste disposal by people that inhabit area have great impact on increase of organic matter in soil, vegetable food products such as: Manihot esculenta, Euterpe oleracea, Oenocarpus bacaba and; animal order like bones and shells of animals (armadillo, tortoise, crab, shells); produce huge amount of organic matter that do decompose (Costa et al., 2013). The Black Earth soils are located in areas like waterways, marginal highs, lowland areas, dry land, occupying about one hectare; however, this dimension could reach hundreds of hectares (ha) when are located along river sides (Smith, 1980). The historical occupation of Brazilian Amazon has been intrinsically linked with permeation through floodplains, which is an abundant source of animal protein due to easy capture of fish, turtles and manatee. Due to richness of soils, lands sustain higher yields and require less effort for the preparation of area. Besides, this is representing a significant and perhaps sole transportation route for pre-Columbian populations (Denevan, 1996; Glaser and Birk, 2012). In mid-2000s, these coastal areas with the archaeological sites of (Alunorte, Bittencourt, and Jambuaçu sites), were studied as touching industrial activities related to bauxite mininga and kaolin in the Paragominas city, Brazil, and its surroundings. Therefore, the built infrastructures (pipeline, transmission line, roads, diversion and siltation of streams) have impacts on the community that can cause significant and often irreversible environmental damage. By assessment of chemical elements, 
anthropogenic impact on referred site areas can be evaluated. The aims of this study were to evaluate modification of chemical attributes of soils promoted by anthropic activities carried out in areas around archaeological sites soils in Northeast Pará Islands region.

\section{Results and Discussion}

\section{Attributes of the studied archaeological sites}

For $\mathrm{pH}$ values observed that Alunorte site on horizon showed values of 3.34 and Bittencourt and Jambuaçu sites presented values of 4.81 and 4.97, respectively on the BA and B1 horizons, and $\mathrm{pH}$ values for Bittencourt and Jambuaçu sites were equal and differed from $\mathrm{pH}$ values of Alunorte site (Table 1 and 2). Silva et al. (2011) found $\mathrm{pH}$ values varying from 5.1 to 6.4 in five soils of archaeological sites in Amazon region.

The carbon values of Jambuaçu site presented highest averages in all soil horizons compared to Alunorte and Bittencourt sites, with values of $31.02 ; 26.00 ; 23.72 ; 9.58$; and $6.48 \mathrm{~g} \mathrm{~kg}^{-1}$ in horizons $\mathrm{A} ; \mathrm{AB} ; \mathrm{BA} ; \mathrm{B} 1$; and $\mathrm{B} 2$, respectively. In a similar way, organic matter values were highest in Jambuaçu site, in which values of $53.47 \mathrm{~g} \mathrm{~kg}^{-1}$ on A horizon, and $44.83 \mathrm{~g} \mathrm{~kg}^{-1}$ on $\mathrm{AB}$ horizon is shown (Table 1). These values were higher than those found by Costa et al. (2009). Organic matter content of $40.9 \mathrm{~g} \mathrm{~kg}^{-1}$ was discovered at Manduquinha site and such differences demonstrate that $\mathrm{ABE}$ are not homogeneous as relating to fertility, having variations in $\mathrm{ABE}$ properties of same region with the same stain (Lehmann et al., 2003).

Nitrogen values at Jambuaçu site presented higher values of 4.66; 3.39; and $2.33 \mathrm{~g} \mathrm{~kg}^{-1}$ in A, AB, BA horizons. Potassium values at Bittencourt and Jambuaçu sites, independent of horizons, were higher than those observed at Alunorte site.

The potassium values in Jambuaçu site varied from 0.25 to $4.23 \mathrm{cmol}_{\mathrm{c}} \mathrm{dm}^{-3}$, while Alunorte and Bittencourt sites have values ranging from 0.03 to $0.05 \mathrm{cmol}_{\mathrm{c}} \mathrm{dm}^{-3}$ and 0.36 to 2.60 $\mathrm{cmol}_{\mathrm{c}} \mathrm{dm}^{-3}$, respectively. Falcão and Borges (2006) found reduced levels of $\mathrm{K}^{+}$in Black Earths of Iranduba city, Brazil, in which fertilized Black Earths showed value of $0.19 \mathrm{cmol}_{\mathrm{c}}$ $\mathrm{dm}^{-3}$, compared to $0.12 \mathrm{cmolc} \mathrm{dm}^{-3}$ in non-fertilized areas.

At the Bittencourt and Jambuaçu sites, calcium and magnesium values were higher compared to the Alunorte site. In A horizon, $\mathrm{Ca}$ levels presented difference in sites, observed that minimum value found at Alunorte site was of $0.0 \mathrm{cmol}_{\mathrm{c}} \mathrm{dm}^{-3}$ whereas, maximum value recorded at Jambuaçu site with $1.03 \mathrm{cmol}_{\mathrm{c}} \mathrm{dm}^{-3}$. The variation is possibly associated with the current land use, soil losses due to surface erosion, the geographic localization to the size and duration of indigenes occupation (Sjoberg, 1976).

$\mathrm{Mg}$ presented a maximum value of $0.70 \mathrm{cmol}_{\mathrm{c}} \mathrm{dm}^{-3}$ in BA horizon at Jambuaçu site in comparison with $0.01 \mathrm{cmol}_{\mathrm{c}} \mathrm{dm}^{-3}$ in same horizon (BA horizon) at Alunorte and Bittencourt sites. The low magnesium levels in these areas is typical of Brazilian Amazon acidic soils where $\mathrm{Mg}$ is usually found in low concentrations in soil solution, due to loss of stages along profile, poverty of source material or low soil $\mathrm{pH}$ or even as a result of the withdrawal of original forest for cultivation (Jakelaitis et al., 2008).

The average phosphorus content at Jambuaçu site was $67.60 \mathrm{mg} \mathrm{kg}^{-1}$, whereas Alunorte and Bittencourt sites presented values of $1.90 \mathrm{mg} \mathrm{kg}$ and $3.84 \mathrm{mg} \mathrm{kg}^{-1}$, respectively. The Jambuaçu site presented horizon BA phosphorus values of $142.00 \mathrm{mg} \mathrm{kg}^{-1}$ (Table 1), similar to those described by Campos et al. (2011), which obtained a value of $144 \mathrm{mg} \mathrm{kg-1}$ in yellow red Argissol, but in most superficial layer of the soil, in A1 horizon.

The Jambuaçu site obtained better results than other sites as regard as attributes of $\mathrm{CEC}_{\mathrm{ef}}$ and aluminum saturation $(\mathrm{m} \%)$. On other hand, $\mathrm{CEC}_{\mathrm{ef}}$ attribute is merely present in horizon $\mathrm{BA}$ and average between sites was similar. The difference between means pertaining aluminum saturation attribute $(\mathrm{m} \%)$ was present only in A horizon. The sum of base values was higher at Bittencourt and Jambuaçu sites in all horizons except for B2 horizon.

The soils of archaeological sites showed V\% values that are characterized as dystrophic soils with high degree of weathering of tropical regions.

The impact of human activities on soils, samples sites of ABE from adjacent areas can be recognized using multivariate analysis. In other words, these are similar to hierarchical cluster analysis according to variables used in the work, obtaining a significant change in Euclidean distance values presented as a percentage; set of variables analyzed and enabled classification of groups (Fig 1).

\section{Principal component analysis}

The possibility of utilization of selected variables for distinction of studied areas and setting of variables admitted a curtailment in Euclidean distance of $30 \%$, favoring a division of groups. This indicates that with combined use of chemical attributes, it is possible to sort data. Performing division of groups, it was possible to sort data into two groups: G1: comprising Alunorte (S1) and Bittencourt (S2) sites, and G2: comprising Jambuaçu site (S3) (Fig 1).

In formed groups, soils at Alunorte and Bittencourt sites presented similar chemical properties, while Jambuaçu site for presenting values of chemical attributes $\mathrm{P}, \mathrm{C}, \mathrm{MO}, \mathrm{Ca}^{+2}$, $\mathrm{Mg}^{+2}, \mathrm{pH}, \mathrm{K}^{+}$, and $\mathrm{CTC}_{\mathrm{ef}}$, higher than other sites allowed formation of a group with a higher hierarchical level compared to group 2. According to Yemefack et al. (2005), principal component analysis allows grouping of variables with similar characteristics to one another and with an increase of variability between the groups formed.

The correlation between variables and principal components (PCs) allows characterization of variables as most discriminating in formation and differentiation of soils. As percentage of variance explained by PCs, it is verified that first and second components are responsible for $83.45 \%$ of total variance (CP1: 59.93\%; CP2: 23.52\%) (Fig 2).

From the information, it was verified that 16 evaluated variables, with 25 observations, represented original data set of each area. This shows dimensionality reduction of original variables with a loss of explanation of less than $20 \%$ in the soils of sites studied (Alunorte, Bittencourt, and Jambuaçu sites). Correlation in the unit circle showed that variables $\mathrm{CEC}_{\mathrm{ef}}$ and organic matter were main impact to distinguish between sites studied and sum of bases variables.

\section{Materials and Methods}

\section{Study location}

The study was conducted at three sites with Archaeological Black Earth soils (ABE) in Abaetetuba city, Barcarena city, 
Table 1. An average test for chemical attributes at the Alunorte (S1), Bittencourt (S2) and Jambuaçu (S3) sites in the horizons A, AB and BA.

\begin{tabular}{|c|c|c|c|c|c|c|c|c|c|}
\hline \multirow{3}{*}{ Variables } & \multicolumn{9}{|c|}{ Horizons } \\
\hline & \multicolumn{3}{|l|}{ A } & \multicolumn{3}{|l|}{$\mathrm{AB}$} & \multicolumn{3}{|l|}{ BA } \\
\hline & S1 & S2 & S3 & S1 & S2 & S3 & S1 & S2 & S3 \\
\hline $\mathrm{pH}$ & $3.34 \mathrm{a}^{*}$ & $4.81 \mathrm{~b}$ & $4.97 \mathrm{~b}$ & $4.44 a$ & $4.73 a$ & $4.96 a$ & $4.66 a$ & $4.82 \mathrm{ab}$ & $5.25 \mathrm{~b}$ \\
\hline $\mathrm{C}$ & 14. $54 \mathrm{a}$ & $17.84 \mathrm{a}$ & $31.02 \mathrm{~b}$ & $9.69 a$ & $11.54 \mathrm{a}$ & $26.00 \mathrm{~b}$ & $6.78 \mathrm{a}$ & $8.30 \mathrm{a}$ & $23.72 b$ \\
\hline $\mathrm{OM}$ & $25.06 \mathrm{a}$ & $30.76 a$ & $53.47 \mathrm{~b}$ & $16.71 \mathrm{a}$ & $19.89 a$ & $44.83 b$ & $11.70 \mathrm{a}$ & $14.32 \mathrm{a}$ & $40.89 \mathrm{~b}$ \\
\hline $\mathrm{N}$ & $1.48 \mathrm{ab}$ & $1.46 \mathrm{a}$ & $4.66 \mathrm{~b}$ & $1.48 \mathrm{a}$ & $1.27 \mathrm{a}$ & $3.39 \mathrm{~b}$ & $1.26 \mathrm{a}$ & $0.95 \mathrm{a}$ & $2.33 b$ \\
\hline $\mathrm{C} / \mathrm{N}$ & $9.84 \mathrm{a}$ & $26.62 a$ & $7.75 \mathrm{a}$ & $6.38 \mathrm{a}$ & $22.24 \mathrm{a}$ & $8.60 \mathrm{a}$ & $5.02 \mathrm{a}$ & $18.99 a$ & $9.01 \mathrm{~b}$ \\
\hline $\mathrm{Na}$ & $0.01 \mathrm{a}$ & $0.08 \mathrm{~b}$ & $0.11 b$ & $0.39 \mathrm{ab}$ & $0.06 \mathrm{a}$ & $0.08 b$ & $0.45 a$ & $0.05 b$ & $0.06 \mathrm{~b}$ \\
\hline K & $0.05 a$ & $2.60 \mathrm{~b}$ & $4.23 b$ & $0.05 \mathrm{a}$ & $1.66 \mathrm{~b}$ & $2.33 b$ & $0.04 a$ & $1.17 \mathrm{~b}$ & $1.39 \mathrm{~b}$ \\
\hline $\mathrm{Ca}$ & $0.00 \mathrm{a}$ & $0.47 b$ & $1.03 \mathrm{~b}$ & $0.00 \mathrm{a}$ & $0.19 \mathrm{ab}$ & $0.29 b$ & $0.00 \mathrm{a}$ & $0.11 \mathrm{a}$ & $0.42 b$ \\
\hline $\mathrm{Mg}$ & $0.00 \mathrm{a}$ & $0.26 \mathrm{a}$ & $0.62 b$ & $0.00 \mathrm{a}$ & $0.18 b$ & $0.34 \mathrm{~b}$ & $0.01 \mathrm{a}$ & $0.01 \mathrm{a}$ & $0.70 \mathrm{~b}$ \\
\hline SB & $0.06 \mathrm{a}$ & $3.41 \mathrm{~b}$ & $6.28 c$ & $0.44 a$ & $2.09 \mathrm{ab}$ & $3.32 \mathrm{~b}$ & $0.54 \mathrm{a}$ & $1.42 \mathrm{ab}$ & $3.22 \mathrm{~b}$ \\
\hline $\mathrm{H}+\mathrm{Al}$ & $6.75 \mathrm{a}$ & $5.66 a$ & $9.68 \mathrm{~b}$ & $4.52 \mathrm{a}$ & $5.49 \mathrm{ab}$ & $8.53 b$ & $3.99 \mathrm{ab}$ & $3.86 \mathrm{a}$ & $7.34 \mathrm{~b}$ \\
\hline $\mathrm{Al}$ & $2.23 \mathrm{a}$ & $1.49 \mathrm{a}$ & $1.40 \mathrm{a}$ & $1.27 \mathrm{a}$ & $1.70 \mathrm{a}$ & $2.43 b$ & $1.37 \mathrm{a}$ & $1.56 \mathrm{ab}$ & $1.72 b$ \\
\hline $\mathrm{CEC}_{\mathrm{ef}}$ & $6.80 \mathrm{a}$ & $10.56 \mathrm{a}$ & $18.23 b$ & $5.20 \mathrm{a}$ & $9.28 \mathrm{a}$ & $14.71 \mathrm{~b}$ & $4.90 \mathrm{a}$ & $6.85 a$ & $13.05 b$ \\
\hline V & $1.00 \mathrm{a}$ & $32.37 b$ & $34.00 \mathrm{~b}$ & $11.50 \mathrm{a}$ & $21.00 \mathrm{a}$ & $19.5 \mathrm{a}$ & $13.50 \mathrm{a}$ & $19.29 a$ & $20.50 \mathrm{a}$ \\
\hline $\mathrm{m}$ & $32.79 \mathrm{a}$ & $14.89 \mathrm{ab}$ & $9.95 b$ & $27.23 \mathrm{a}$ & $19.08 \mathrm{~b}$ & $18.18 \mathrm{~b}$ & $27.93 \mathrm{a}$ & $24.83 a$ & $12.48 \mathrm{a}$ \\
\hline $\mathrm{P}$ & $5.00 \mathrm{a}$ & $8.48 \mathrm{a}$ & $49.00 \mathrm{~b}$ & $2.50 \mathrm{a}$ & $5.42 \mathrm{a}$ & $60.50 \mathrm{~b}$ & $0.50 \mathrm{a}$ & $2.97 \mathrm{a}$ & $142.0 \mathrm{~b}$ \\
\hline
\end{tabular}

*Averages followed the same letters on the line do not differ significantly by Tukey's test at the level of $5 \%$ of probability. Units of the variables: $\mathrm{pH}\left(\mathrm{H}_{2} \mathrm{O}\right), \mathrm{C}, \mathrm{OM}, \mathrm{N}$, $\mathrm{C} / \mathrm{N}, \mathrm{Na}\left(\mathrm{g} \mathrm{kg}^{-1}\right), \mathrm{K}, \mathrm{Ca}, \mathrm{Mg}, \mathrm{SB}, \mathrm{H}+\mathrm{Al}, \mathrm{CEC}_{\mathrm{ef}}\left(\mathrm{cmol}_{\mathrm{c}} \mathrm{dm}^{-3}\right), \mathrm{V}, \mathrm{m}(\%)$ and $\mathrm{P}\left(\mathrm{mg} \mathrm{kg}^{-1}\right)$.

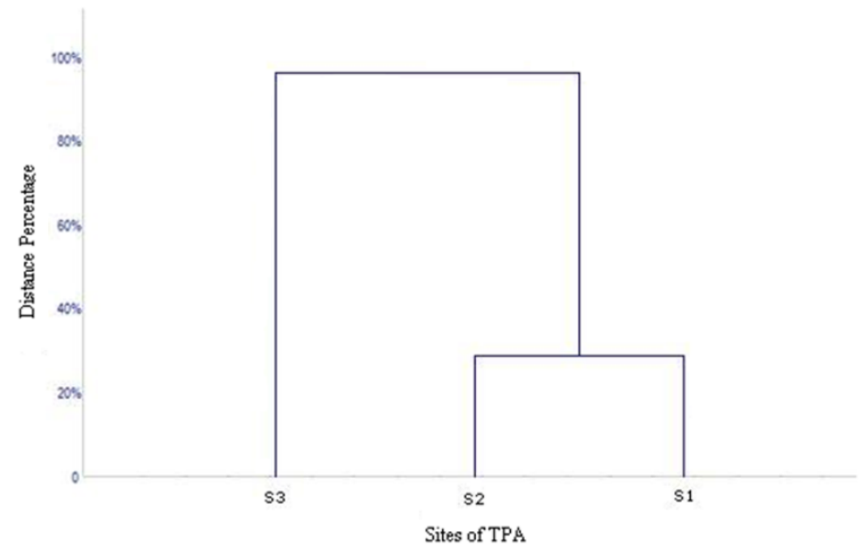

Fig 1. The dendogram regarding the interrelationships to chemical attributes by the average Euclidean distance, in the soil at the Alunorte, Bittencourt and Jambuaçu sites.

Table 2. An average test for chemical attributes at the Alunorte (S1), Bittencourt (S2) and Jambuaçu (S3) sites in the horizons B1 and $\mathrm{B} 2$.

\begin{tabular}{|c|c|c|c|c|c|c|}
\hline \multirow{3}{*}{ Variables } & \multicolumn{6}{|c|}{ Horizons } \\
\hline & \multicolumn{3}{|l|}{ B1 } & \multicolumn{3}{|c|}{ B2 } \\
\hline & S1 & S2 & S3 & S1 & S2 & S3 \\
\hline $\mathrm{pH}$ & 4.83ab* & $4.86 \mathrm{a}$ & $5.30 \mathrm{~b}$ & $4.83 \mathrm{a}$ & $4.91 \mathrm{a}$ & $5.19 a$ \\
\hline $\mathrm{C}$ & $4.85 \mathrm{a}$ & $5.34 \mathrm{a}$ & $9.58 \mathrm{~b}$ & $2.91 \mathrm{a}$ & $3.67 \mathrm{a}$ & $6.84 b$ \\
\hline $\mathrm{OM}$ & $8.35 \mathrm{a}$ & $9.22 \mathrm{a}$ & $16.52 b$ & $5.01 \mathrm{a}$ & $6.33 \mathrm{a}$ & $11.80 \mathrm{~b}$ \\
\hline $\mathrm{N}$ & $0.92 \mathrm{a}$ & $0.84 a$ & $1.30 \mathrm{a}$ & $0.83 a$ & $0.83 a$ & $0.89 \mathrm{a}$ \\
\hline $\mathrm{C} / \mathrm{N}$ & $4.76 a$ & $8.75 \mathrm{a}$ & $6.17 \mathrm{a}$ & $3.15 \mathrm{a}$ & 4.89ab & $7.51 \mathrm{~b}$ \\
\hline $\mathrm{Na}$ & $0.37 \mathrm{a}$ & $0.03 b$ & $0.05 b$ & $0.49 \mathrm{a}$ & $0.03 b$ & $0.02 b$ \\
\hline K & $0.03 \mathrm{a}$ & $0.58 \mathrm{ab}$ & $1.20 \mathrm{~b}$ & $0.03 \mathrm{a}$ & $0.36 \mathrm{~b}$ & $0.25 b$ \\
\hline $\mathrm{Ca}$ & $0.00 \mathrm{a}$ & $0.09 \mathrm{a}$ & $0.31 b$ & $0.00 \mathrm{a}$ & $0.05 a$ & $0.34 b$ \\
\hline $\mathrm{Mg}$ & $0.00 \mathrm{a}$ & $0.09 \mathrm{ab}$ & $0.13 b$ & $0.00 \mathrm{a}$ & $0.07 \mathrm{a}$ & $0.28 \mathrm{~b}$ \\
\hline SB & $0.44 \mathrm{a}$ & $0.80 \mathrm{a}$ & $2.31 \mathrm{~b}$ & $0.79 \mathrm{a}$ & $0.51 \mathrm{a}$ & $0.92 \mathrm{a}$ \\
\hline $\mathrm{H}+\mathrm{Al}$ & $3.81 \mathrm{ab}$ & $2.61 \mathrm{a}$ & $4.41 \mathrm{~b}$ & $2.41 \mathrm{a}$ & $2.92 \mathrm{a}$ & $1.90 \mathrm{a}$ \\
\hline $\mathrm{Al}$ & $1.30 \mathrm{a}$ & $1.50 \mathrm{a}$ & $1.40 \mathrm{a}$ & $1.09 \mathrm{a}$ & $1.24 \mathrm{a}$ & $1.19 \mathrm{a}$ \\
\hline CECef & $4.10 \mathrm{a}$ & $4.91 \mathrm{a}$ & $8.08 \mathrm{~b}$ & $2.85 \mathrm{a}$ & $4.67 \mathrm{a}$ & $4.67 \mathrm{a}$ \\
\hline V & $9.50 \mathrm{a}$ & $15.15 \mathrm{ab}$ & $25.00 \mathrm{~b}$ & $14.50 \mathrm{a}$ & $12.42 \mathrm{a}$ & $18.72 \mathrm{a}$ \\
\hline $\mathrm{m}$ & $33.25 \mathrm{a}$ & $31.19 a$ & $17.76 \mathrm{a}$ & $37.90 \mathrm{a}$ & $30.89 a$ & $30.89 a$ \\
\hline $\mathrm{P}$ & $1.50 \mathrm{a}$ & $1.44 \mathrm{a}$ & $53.50 \mathrm{~b}$ & $0.00 \mathrm{a}$ & $0.89 \mathrm{a}$ & $33.00 \mathrm{~b}$ \\
\hline
\end{tabular}

*Averages followed the same letters on the line do not differ significantly by Tukey's test at the level of $5 \%$ of probability.Units of the variables: $\mathrm{pH}\left(\mathrm{H}_{2} \mathrm{O}\right), \mathrm{C}, \mathrm{OM}, \mathrm{N}$, $\mathrm{C} / \mathrm{N}, \mathrm{Na}\left(\mathrm{g} \mathrm{kg}^{-1}\right), \mathrm{K}, \mathrm{Ca}, \mathrm{Mg}, \mathrm{SB}, \mathrm{H}+\mathrm{Al}, \mathrm{CEC}_{\mathrm{ef}}\left(\mathrm{cmol}_{\mathrm{c}} \mathrm{dm}^{-3}\right), \mathrm{V}, \mathrm{m}(\%)$ and $\mathrm{P}\left(\mathrm{mg} \mathrm{kg}^{-1}\right)$. 


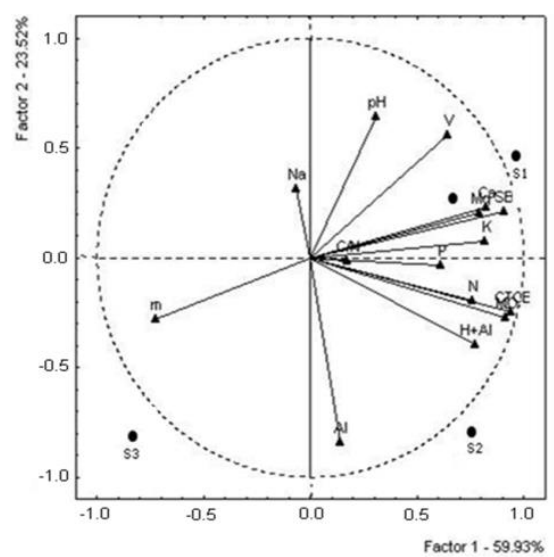

Fig 2. Biplot of the main components of the chemical attributes in the soil at the Alunorte, Bittencourt and Jambuaçu sites.

and Moju city, State of Pará, Brazil. The Alunorte site $\left(01^{\circ} 32^{\prime} 21^{\prime \prime} \mathrm{S}, 48^{\circ} 43^{\prime} 31.7^{\prime \prime} \mathrm{W}\right)$ is located at the left bank of Murucupi stream, Barcarena city; the Bittencourt site (01 $\left.44^{\prime} 15^{\prime \prime} \mathrm{S}, 48^{\circ} 43^{\prime} 32.0^{\prime \prime} \mathrm{W}\right)$ is located at the left bank of Arapiranga do Beja stream, Abaetetuba city; and the Jambuaçu site $\left(01^{\circ} 53^{\prime} 06^{\prime \prime} \mathrm{S}, 48^{\circ} 36^{\prime} 18^{\prime \prime} \mathrm{W}\right)$ is located at the right bank of the Jambuaçu stream, Moju city. The climate is equatorial, with Am type in Abaetetuba and Barcarena, and Ami in Moju, according to Köppen climate classification. The average annual temperature in area is $26^{\circ} \mathrm{C}$, with an average annual rainfall of 2,000 and a relative humidity of $85 \%$. The vegetation in areas mainly consists of secondary vegetation and dense forest, with presence of Euterpe oleracea, and Mauritia flexuosa. The soils of Alunorte and Bittencourt sites were classified as Latosol Yellow, with medium sand texture, while the soil of Jambuaçu site was classified as Plinthosol Argiluvico with medium texture according to methodology used by Santos et al. (2005).

\section{Experimental design}

The archeological sites for this study were chosen based on the facts that they are more preserved and have lesser extent. The experimental block design has been adopted randomly with different number of repetitions. Seven profiles were selected at the Alunorte site, twelve at the Bittencourt site and six ABE profiles at Jambuaçu site. The soil collection was done between 2004-2006 years.

\section{Measured characteristics}

The soil chemical properties were determined: $\mathrm{pH}$ in water, potential acidity $\left(\mathrm{H}+\mathrm{Al}^{3+}\right)$ was extracted by ethyl; Phosphorus (P) extracted with Mehlich-1, calcium $\left(\mathrm{Ca}^{2+}\right)$, magnesium $\left(\mathrm{Mg}^{2+}\right)$ and aluminum $\left(\mathrm{Al}^{3+}\right)$ exchangeable extracted by $\mathrm{KCl}$; carbon $(\mathrm{C})$, nitrogen $(\mathrm{N})$ by the Kjeldahl method, and organic matter $(\mathrm{OM})$ and potassium $\left(\mathrm{K}^{+}\right)$ determined by flame photometry according to Donagema et al. (2011). The results of chemical analyzers were used to estimate the relationship $\mathrm{C} / \mathrm{N}$, sum of bases (SB), total cation exchange capacity (CEC), base saturation (V\%), and aluminum $(\mathrm{m} \%)$.

\section{Statistical analysis}

Data on soil chemical properties were subjected to Turkey's test; between areas of archaeological black earth through statistical software Minitab $14^{\circledR}$ (Minitab, 2000). The principal component analysis (PCA) and cluster analysis (cluster) were done from ascending hierarchical classification using the software R (R Development Core Team, 2011).

\section{Conclusion}

The soils at Alunorte and Bittencourt archaeological sites did not possess characteristics of Archaeological Black Earth soil. The soil at Jambuaçu site presented typical characteristics of Archaeological Black Earth soil, especially in its phosphorus values. The present anthropic actions, to which Archaeological sites are subjected to, changed chemical properties and characterized these as Archaeological Black Earth soils.

\section{Acknowledgements}

This study was possible with technical support from the Museu Paraense Emílio Goeldi and the Federal Rural University of Amazônia.

\section{References}

Aquino ER, Junior MJ, Campos CCM, Oliveira AI, Bahia SRSA, Santos CAL (2017) Characteristics of color and iron oxides of clay fraction in Archeological Dark Earth in Apuí region, southern Amazonas. Geoderma. 262: 35-44.

Campos MCC, Ribeiro MR, Souza Júnior VS, Ribeiro Filho MR, Souza RVCC, Almeida MC (2011) Characterization and classification of archaeological dark earths from the Middle Madeira river region. Bragantia. 70: 598-609.

Costa JA, Costa ML, Kern DC (2013) Analysis of the spatial distribution of geochemical signatures for the identification of prehistoric settlement patterns in ADE and TMA sites in the lower Amazon Basin. J Archaeol Sci. 40: 2771-2782.

Costa JA, Kern DC, Costa ML, Rodrigues TE, Kämpf N, Lehmann J, Frazão FJL (2009) Geoquímica das Terras Pretas Amazônicas. In: Teixeira WG, Kern DC, Madari BE, Lima HN, Woods W. As terras pretas de índio da Amazônia: Sua caracterização e uso deste conhecimento na criação de novas áreas. Manaus: Embrapa Amazônia Ocidental. p.162-171.

Denevan WM (1996) A bluff model of riverine settlement in prehistoric Amazonia. Ann Assoc Am Geogr. 86: 654-681.

Donagema GK, Campos DVB, Calderano SB, Teixeira WG, Viana JHM (2011) Manual de métodos de análise de solos. $2^{\text {rd }}$ edn. Rio de Janeiro, Embrapa Solos. 230p.

Falcão NPS, Borges LF (2006) Effect of amazonian dark earth fertility on nutritional status and fruit production of papaya (Carica papaya L.) in Central Amazonia. Acta Amaz. 36: 401-406. 
Glaser B, Birk JJ (2012) State of the scientific knowledge on properties and genesis of Anthropogenic Dark Earths in Central Amazonia (terra preta de Índio). Geochim Cosmochim Acta. 82: 39-51.

Jakelaitis A, Silva AA, Santos JB, Vivian R (2008) Quality of soil surface layer under forest, pasture and cropped areas. Pesq Agropec Trop. 38: 118-127.

Lehmann J, Silva JP, Steiner C, Nehls T, Zech W, Glaser B (2003) Nutrient availability and leaching in an archaeological Anthrosol and a Ferralsol of the Central Amazon basin: fertilizer, manure and charcoal amendments. Plant Soil. 249: 343-357.

Lima HN, Schaefer CER, Mello JWV, Gilkes RJ, Ker JC (2002) Pedogenesis and pre-Columbian land use of "Terra Preta Anthrosols" (Indian black earth") of Western Amazonia. Geoderma. 110: 1-17.

Pessoa JPFSE, Santana PG (2017) One approach to phosphorus in Archaeological Black Earth. Sci Amaz. 6: 61-70.
Minitab Release 14.1 (2000) Statistical software. US/Canadá. R Development Core Team (2011) R: A language and environment for statistical computing. R Foundation for Statistical Computing.

Santos RD, Lemos RC, Santos HG, Ker JC, Anjos LHC (2005) Manual de descrição e coleta de solo no campo. $5^{\text {rn }}$ ed. Viçosa, SBCS/EMBRAPA/CNPS. 100p.

Silva FWR, Lima HN, Teixeira WG, Motta MB, Santana RM (2011) Chemical and mineralogical characterization of anthropic soils (Amazonian dark earths) in the Central Amazon. Rev Bras Cienc Solo. 35: 673-681.

Sjoberg A (1976) Phosphate analysis of antropic soils. J Field Archaeol. 3: 447-454.

Smith NJH (1980) Anthrosols and Human Carrying Capacity in Amazonia. Ann Assoc Am Geogr. 70: 553-566.

Yemefack M, Rossiter DG, Njomgang R (2005) Multi-scale characterization of soil variability within an agricultural landscape mosaic system in southern Cameroon. Geoderma. 125: 117-143. 